\title{
LA ESCRIBANÍA LUSO-CASTELLANA DE ISABEL, PRIMOGÉNITA DE LOS REYES CATÓLICOS
}

\author{
Nicolás Ávila SeOANE ${ }^{1}$ \\ Universidad Complutense de Madrid
}

Recibido: 25 de febrero de 2019

Aceptado: 10 de mayo de 2019

\begin{abstract}
Resumen
Estudio diplomático de los documentos intitulados por la infanta Isabel, hija mayor de los Reyes Católicos, princesa y luego reina de Portugal, conservados en el Arquivo Nacional Torre do Tombo, el Archivo General de Simancas, la Real Academia de la Historia y la Biblioteca Nacional de España; tras revisar el actual estado de las investigaciones sobre Paleografía y Diplomática en la Baja Edad Media portuguesa, se señalan para cada tipología las influencias achacables a una y otra cancillería, dando lugar en ocasiones a modelos híbridos en cuanto a soporte, escritura, lengua, formulario...
\end{abstract}

\section{Palabras clave}

Diplomática, Castilla, Portugal, Reyes Católicos, infanta Isabel.

\begin{abstract}
Diplomatic study of the documents signed by the infanta Isabel, eldest daughter of the Catholic Monarchs, princess and then queen of Portugal, preserved in the Arquivo Nacional Torre do Tombo, the Archivo General de Simancas, the Real Academia de la Historia and the Biblioteca Nacional de España. After reviewing the current state of research on Paleography and Diplomatics in the Portuguese Late Middle Ages, influences from both chancelleries for each typology are indicated, sometimes resulting in hybrid models with regard to their support, writing, language, form, etc.
\end{abstract}

\section{Keywords}

Diplomatics, Castile, Portugal, Catholic Monarchs, infant Isabella.

\section{Resumo}

Estudo diplomático dos documentos da infanta Isabel, filha mais velha dos Reis Católicos, princesa e depois rainha de Portugal, conservados no Arquivo Nacional Torre do Tombo, no Archivo General de Simancas, na Real Academia de la Historia e na Biblioteca Nacional de España; depois de revisar o estado atual da pesquisa sobre Paleografia e Diplomática na Baixa Idade Média portuguesa, para cada tipo são indicadas as influências atribuíveis a ambas as chancelarias, ou os modelos híbridos em termos de suporte, escrita, linguagem, formulário...

\footnotetext{
1 Departamento de Historia de América y Medieval y Ciencias Historiográficas. Facultad de Geografía e Historia. Universidad Complutense de Madrid. Correo electrónico: niavila@ucm.es. OrCiD: https://orcid. org/0000-0002-2512-0522
} 


\section{Palabras chave}

Diplomática, Castela, Portugal, Reis Católicos, infanta Isabel.

En el séquito de cualquier infanta que salía al extranjero para casarse, solía haber al menos un secretario o un escribano. Tras el regio matrimonio, la esposa aparecería con frecuencia en las intitulaciones del marido con arreglo a los usos diplomáticos allí vigentes. Pero había ciertos asuntos sobre los que ella podía dar sus propios otorgamientos, generalmente garantizados o redactados por esos oficiales de su compañía, como eran gestionar su casa, escribir a parientes o extender últimas voluntades. En estos casos la elección de idioma, formulario, escritura o modalidad fluctuaba y podían mezclarse en el mismo instrumento usos castellanos y foráneos.

Veremos aquí los diplomas particulares de la primogénita de los Reyes Católicos Isabel. En 1479, con 10 años, sus padres la habían prometido al príncipe Alfonso de Portugal, primogénito de Juan II, ordenando su traslado al castillo de Moura, donde debería permanecer al cuidado de Beatriz de Viseo, tía del rey luso, hasta ser núbil, si bien regresó a Castilla en 1483. La boda se celebró finalmente en 1490, pero al año siguiente el príncipe falleció tras caer de un caballo. Durante mucho tiempo Isabel rehusó volver a casarse, queriendo incluso tomar los hábitos, pero finalmente en septiembre de 1497 desposó al nuevo rey de Portugal Manuel I, tío de su primer marido. El matrimonio no duró ni un año, al morir la reina en su primer parto el 23 de agosto de $1498^{2}$.

De ella contamos con diecisiete escritos: Arquivo Nacional Torre do Tombo, catorce originales y tres insertos ${ }^{3}$; dos en el de Simancas, original y copia ${ }^{4}$; otros dos en la Real

\footnotetext{
2 Sobre ella pueden verse: CoRdEIRO DE SousA, "Notas acerca de la boda de Isabel de Castilla...”, pp. 33-51; SuÁrez Fernández y Ezquerra Abadía, "Isabel, infanta de Castilla y Aragón”, pp. 506-507; Montes RomeroCAмасно, "Un episodio más de las relaciones político-familiares hispano-portuguesas...", pp. 539-550; SANZ Hermida, “A vos Diana primera leona...”, pp. 379-394; Alonso Ruiz, "Dos cortes en 1490: el enlace entre Isabel de Castilla...", 123-139, "Doña Isabel de Castilla, entre la magnificencia castellana y la portuguesa...", pp. 105-122, "La muerte de la reina de Portugal en Zaragoza en 1498...", pp. 242-246, y "Emmanuelis iter in Castellam: el viaje de los reyes de Portugal por Castilla en 1498”, pp. 2537-2554; FERnÁndEz LuZÓN, "Isabel de Castilla y Aragón”, pp. 400-402; Guimarães SÁ, Rainhas consortes de dom Manuel I; NoGALES Rincón, "Las lágrimas de la infanta de Castilla...", pp. 108-128, "La cultura del pacto en las relaciones diplomáticas luso-castellanas...", pp. 121-144, y "Los proyectos matrimoniales hispano-portugueses...", pp. 43-68; Martínez Alcorlo, "La literatura en torno a las hijas de los Reyes Católicos...", pp. 253-266, Antonio de Nebrija: Epithalamivm en honor de las bodas..., "El Epithalamium de Antonio de Nebrija y la Oratio de Cataldo Parisio Sículo..., pp. 955-972, La Literatura en torno a la primogénita de los Reyes Católicos..., tesis doctoral inédita, y “"Estampas para un libro»: la infanta Isabel de Castilla...”, pp. 509-530, y ÁviLA SeOAne, “Casos de original múltiple...", pp. 7-115, y "La escritura de las reinas de Portugal...", pp. 39-76.

3 Arquivo Nacional Torre do Tombo (ANTT), Chancelaria régia, Chancelaria de dom Manuel I, liv. 16, ff. 130v, 130v-131 y 131-131v; Corpo cronológico, parte I, maço 1, núms. 47, 49 y 50, y Gavetas, gaveta 14, maço 8 , núm. 8 ; gaveta 15 , maço 2 , núms. 3 y 5 ; maço 5 , núm. 21; maço 6 , núm. 6; maço 8 , núm. 9; maço 15, núm. 25; maço 19, núm. 49; maço 24, núm. 8; gaveta 17, maço 1, núm. 9, y maço 9, núm. 4.

4 Archivo General de Simancas (AGS), Patronato real, leg. 50, doc. 31, ff. 101-102v, y Registro General del Sello, leg. 1498-8, núm. 1.
} 
Academia de la Historia, copia y minuta ${ }^{5}$ y un original en la Biblioteca Nacional de España $^{6}$. Recientemente se ha publicado el repertorio completo en la revista De Medio Aevo $^{7}$; gran parte de todo ello permanecía inédito, pues Antonio de la Torre y Luis Suárez solo habían transcrito cinco para los Documentos referentes a las relaciones con Portugal durante el reinado de los Reyes Católicos ${ }^{8}$, colección que incluye el regesto de otro ${ }^{9}$ y la signatura de cuatro más ${ }^{10}$.

\section{Notas sobre Paleografía y Diplomática portuguesas}

Antes de entrar en la tipología diplomática de lo allegado, es necesario advertir que está menos estudiada en conjunto la de allí, pues para Castilla contamos con numerosos manuales y artículos; en Portugal ha pesado más el contenido jurídico que el análisis diplomático. Pionero en esta cuestión, para la Baja Edad Media, fue Armando Luís de Carvalho Homem en su tesis doctoral O desembargo régio (1320-1443), defendida en la Universidad de Porto en 1985, cuya segunda parte, titulada "As fontes", clasifica en carta, alvará y acto legislativo, ajeno este lógicamente al presente trabajo" ${ }^{11}$.

Basándose en los registros de la cancillería, aunque no estructura esas cartas, sí da indicaciones tales como ser el instrumento más corriente, ir en portugués, carecer de invocación, llevar intitulación completa bajo trato de "dom", sentencia "pela graça de Deus" y lista de dominios; alternar dos variantes de cláusula corroborativa (directamente "el rrei o mandou", o bien mediante persona interpuesta: "el rrei o mandou por F., seu vassalo"), y ofrecer data completa. Distingue dos modelos: la carta aberta, más frecuente, validada con el selo grande a cargo del canciller; y la carta cerrada, surgida a finales del siglo XIV, de tono menos imperativo, semejante al de las misivas oficiales

\footnotetext{
Real Academia de la Historia (RAH), Colección Salazar y Castro, A-11, ff. 39v y 189.

Biblioteca Nacional de España (BNE), RES/226/104.

Ávila Seoane, "Documentos de las hijas de los Reyes Católicos: Isabel”, pp. 163-194. Ahí pueden consultarse los textos íntegros.

8 Vol. II, pp. 400 y 401, y vol. III, 1963, pp. 15-18, 18-19 у 20-21.

9 Vol. II, p. 434.

10 Vol. II, p. 401.

11 Versión mecanografiada de la tesis, pp. 54-66 y 107-108 (dedica el resto del capítulo, sobre todo, a la habitual clasificación jurídica, estableciendo seis categorías principales: asuntos de gracia, justicia, hacienda, administración general, traslados y 'diversos'). En 1990 fue publicada por la propia universidad. De la introducción se infiere que el término desembargo es asimilable al nuestro de cancillería: "traduzir-se-á fundamentalmente na elaboração das cartas régias —é na qualidade de redactores que as subscrevemou na validação - como testemunhas presenciais - e eventual publicitação de actos legislativas do monarca (leis, ordenações, regimientos, posturas) ou ainda de acordos e composições —inclusivamente no âmbito das relações com outros soberanos - por ele assumidos" (p. 16). Aunque abundan ya textos de esa índole en internet, buena parte de la bibliografía portuguesa aquí manejada procede del servicio de préstamo interbibliotecario de la Facultad de Geografía e Historia de la Universidad Complutense de Madrid; gracias a la particular atención de sus jefas de Procesos e Información Especializada Amaya Rico Francia y Esther Las Heras Navarro.
} 
castellanas, y cuyo formulario, sin invocación, arranca con dirección, breve intitulación ("nos el rrey"), saludo ("vos envyamos muyto saudar") y notificación ("fazemos vos saber que"); la fecha no pone año, y lleva el sello secreto.

En cuanto al alvará, nacido en las postrimerías del siglo XIV en paralelo a nuestro albalá, es sencillo, en portugués, de materia generalmente económica, en papel e incoado así: breve intitulación ("nos el rrei”), notificación ("fazemos saber") y dirección ("a vos...").

En los últimos años el asunto ha vuelto a ser abordado por diplomatistas noveles ${ }^{12}$ bajo la dirección del profesor Armando Homem, avanzando en la cronología, pero tomando siempre como base el expresado estudio y como fuente principal los registros de la cancillería. Entre 1996 y 2001 culminaron cinco tesis de máster sobre la de Alfonso V, que denominan tipos diplomáticos a lo que en realidad son categorías jurídicas: provimentos e remuneraçãos de ofícios, doações de bens e direitos, regulamentaçãos do direito de pousada, legitimações...13 Igual hacen otros dos discípulos de Homem: Judite de Freitas, tanto en su tesis doctoral de 1999, relativa a la primera etapa del Africano, como en un artículo de 2009 sobre los despachos de Juan I, Duarte y Alfonso V ${ }^{14}$; y Diogo Faria en 2013 para Manuel I ${ }^{15}$.

Frente a tal penuria, descolla el artículo del profesor Bernardo de Sá Nogueira sobre lo consignado por Juan II y Manuel I al concejo de Montemor-o-Novo, y es ahí donde, en colaboración con un grupo de alumnos, lleva a cabo, ahora sí, su riguroso análisis diplomático ${ }^{16}$. Las tesis de máster leídas en 2006 por dos discípulas suyas siguen la misma línea: la de Sara Loureiro aborda el mandado, la carta régia, el alvará y la carta-missiva en tiempos de Manuel I y Juan III' ${ }^{17}$, y la de Isaura Tereno repara en las dos últimas clases partiendo de los nombramientos regios de oficiales municipales en Lisboa durante la segunda mitad del siglo XVI ${ }^{18}$.

\footnotetext{
12 Para una cumplida bibliografía sobre las cancillerías portuguesas tardomedievales puede verse el artículo de Freitas, "The royal chancellery at the end of the portuguese Middle Ages...", pp. 1-23. Todavía en 1990 el profesor Bernardo de Sá Nogueira denunciaba que "em Portugal, não existe na verdade quem se dedique exclusivamente ao estudo da Diplomática, para os séculos XIV e XV" ("Cartas-missivas, alvarás e mandados...", p. 47).

13 AlmeIda, A chancelaria régia e os seus oficiais em 1462; Borlido, A chancelaria régia e os seus oficiais em 1463; CAPAS, A chancelaria régia e os seus oficiais no ano de 1469; CARVALHO, A chancelaria régia e os seus oficiais em 1468, y Monteiro, A chancelaria régia e os seus oficiais (1464-1465). Para el período anterior es fundamental la consulta de CosTA, "La chancellerie royale portugaise jusq'au milieu du XIII' siècle".

14 FREITAS, «Teemos por bem e mandamos»: a chancelaria régia..., y "Chancelarias régias quatrocentistas portuguesas...", pp. 141-142 y 146.

15 FARIA, A chancelaria de dom Manuel I... La parte relativa a los oficiales de la cancillería fue publicada en el artículo "A burocracia régia e os seus oficiais no tempo de dom Manuel I", pp. 587-607.

16 SÁ Nogueira, "Cartas-missivas, alvarás e mandados...”, pp. 43-129.

17 Loureiro, Afonso Mexia, escrivão da Câmara e da Fazenda... Editada parcialmente en "Reconstituição e análise da documentação...”, pp. 10-47.

18 Tereno, Provisões régias recebidas pela cidade de Lisboa... Resumida en el artículo "Estudo das provisões régias recebidas pela cidade de Lisboa...”, pp. 55-101, resultando especialmente útiles las tablas de las pp. 95-100. Adviértase que, en ambos títulos, provisões alude exclusivamente al nombramiento y no al tipo documental.
} 
Y en cuanto a grafismo, los breves toques que veremos dentro de los caracteres externos de cada categoría documental, apoyan la idea apuntada en 1969 por Eduardo Nunes de que hacia 1387 la cursiva gótica portuguesa sufrió una marcada influencia de la bastarda francesa, probablemente a través de los aquitanos del séquito que acompañó a Filipa de Lancáster para su matrimonio con Juan I; de esa mezcla surge una escritura llamada en ocasiones cortesã, pero diferente de la cortesana de Castilla, en cuya evolución es posible distinguir dos fases: la inicial letra joanina empezará a transformarse desde mediados del siglo XV para dar lugar, ya entrado el XVI, a la manuelina ${ }^{19}$.

Recientemente nuevas tesis de máster dirigidas por Bernardo de Sá Nogueira han insistido en ello ${ }^{20}$ describiendo con detalle ambas grafías y delimitándolas cronológicamente con precisión. De la joanina, Ana Cristina Ferreira (aunque centrada sobre todo en su primera etapa, hasta 1420) dice ser angulosa; con astas y caídos prolongados que, junto con los signos braquigráficos, agotan el interlineado a pesar de su relativa amplitud; ligeramente dextrógira; sin contraste entre trazos gruesos y finos; de clara separación de palabras, y abundantes abreviaturas, en particular para suplir nasales y la vocal $e^{21}$. En la segunda mitad del siglo XV se va volviendo mucho más redondeada, con merma de astiles y caídos, dando lugar a partir de 1500 a la nueva manuelina, estudiada en dos tesinas leídas en 2006 por Maria Teresa Coelho y Sara Loureiro $^{22}$. Es la última letra gótica de la cancillería pues, a partir de la tercera década del siglo XVI se irá implantando la humanística, proceso analizado por el profesor José Marques y por Jorge Paulo, otro discípulo de Sá Nogueira ${ }^{23}$.

\section{La escribanía ${ }^{24}$}

Los catorce despachos de agosto y septiembre de 1491, y otro del 20 de noviembre de 1494, siempre como viuda del príncipe Alfonso de Portugal, van refrendados por Juan de Salinas, "secretario de la prinçesa nuestra señora", en castellano y letra cortesana,

\footnotetext{
19 NunEs, Álbum de Paleografia portuguesa, vol. I, pp. 12-13.

20 Choca la inhibición del resto de especialistas. Los principales álbumes portugueses, al margen del acabado de citar del profesor Nunes, suelen acompañar cada lámina de un comentario, más de contexto histórico que paleográfico, en el que señaladamente la identificación del género de escritura falta o es muy imprecisa: MARQues, Estudos de Paleografia portuguesa, que glosa la colección de Burnam, Palaeographia Iberica. Fac-similés de manuscrits espagnols et portugais...; Román Blanco, Estudos paleográficos, o Marques, Dias y Rodrigues, Álbum de Paleografia. Son igualmente muy parcos al respecto los manuales de Cruz, Paleografia portuguesa: ensaio de manual; SAntos, Ler e compreender a escrita na Idade Média, pp. 100-105, y BerWanger y Leal, Noções de Paleografia e Diplomática, pp. 66-68.

${ }_{21}$ Ferreira, Análise paleográfica de uma escrita de chancelaria régia..., pp. 139-140.

22 Coelho, Existiu uma escrita manuelina?..., pp. 46-79, y Loureiro, Afonso Mexia, escrivão da Câmara e da Fazenda..., y "Reconstituição e análise da documentação...", pp. 10-47.

23 Marques, "Práticas paleográficas em Portugal no século XV", pp. 73-96, y PAulo, A escrita humanística na documentação régia portuguesa de Quinhentos, vol. I, p. III.

24 A diferencia de lo expuesto en el epígrafe anterior sobre las tipologías documentales, el notariado ha sido una de las líneas de investigación más fructíferas en Portugal. Para el período aquí estudiado deben citarse como obras de referencia: CunHA, "Alguns tabeliães do Algarve durante a Idade Média": Pereira,
} 
con independencia del tipo gráfico o idioma del resto del texto ${ }^{25}$. Y es frecuente ver una o dos firmas suyas al reverso, destacando la provisión que dice "Johán de Salinas, chançeller (rúbrica)" "26, o sea, guardián del sello de Isabel, obligado a estar permanentemente a su disposición dondequiera que fuese, tal y como atestiguan las datas tópicas: a finales del verano de 1491 firma en Santarem, donde ella acababa de enviudar mes y medio antes, y por noviembre de 1494 en Madrid, en cuyo alcázar pasó la infanta con sus padres aquel otoño y el invierno ${ }^{27}$.

Según las cuentas de Gonzalo de Baeza, el 14 de julio de 1490 Juan de Salinas ya "tiene cargo de la cámara de la señora prinçesa de Portugal", si bien el 20 de noviembre se especifica que aún era "teniente de su camarero". A partir del 20 de febrero de 1492 se le llama "secretario", ocupación que ya ha quedado manifiesta desde el año anterior, y por la cual recibía periódicas sumas de la madre para hacer frente a los gastos de su primogénita y nóminas de empleados ${ }^{28}$; ello sin perjuicio de seguir oficiando de camarero, como atestiguan una provisión real a su favor del 11 de septiembre de $1492^{29}$, una sobrecarta del 2 de julio de $1493^{30} \mathrm{y}$ un apunte de Baeza del 20 de marzo de $1496^{31}$.

Fernando el Católico le dio título de "escrivano e notario público en la mi corte e en todos los mis rreynos e señoríos" el 17 de junio de 1494 "acatando vuestra sufiçiençia e abilidad", y el mismo día la reina de Castilla ordenaba a los contadores mayores no hacerle justificar dos partidas de 100.000 y 500.000 maravedís destinadas a "algunas cosas conplideras a mi serviçio" ${ }^{32}$.

"O tabelionado em Portugal"; SAntos, "Alguns aspectos do tabelionado em Coimbra..."; SÁ Nogueira, Tabelionado e instrumento público em Portugal...; MAtA, "Alguns profissionais da escrita na Santarém..."; Saraiva, "Tabeliães e notários de Lamego..."; Coelho, "Os tabeliães em Portugal...”; Gomes, "O notariado medieval português...", y BALMORi-PADESCA, "O notariado nas Ordenações afonsinas...".

25 Las tres copias de los libros registro de Manuel I dan los refrendos en portugués, pero los originales han de presumirse también en castellano: "e eu Joam das Salinas, secretario da primcesa nosa sennora, a fiz escrever e nela sobescrevi” (liv. 16, ff. 130v-131v).

26 ANTT, Gavetas, gaveta 15, maço 5, núm. 21.

27 Rumeu de Armas, Itinerario de los Reyes Católicos, pp. 212-216.

28 Torre y del Cerro y Alsina de la Torre, Cuentas de Gonzalo de Baeza..., vol. I, pp. 315, 347 y 412, y vol. II, pp. 14, 16, 39, 44, 119, 122, 126, 236 y 419-420.

29 AGS, Registro General del Sello, leg. 1492-9, núm. 40. Informa además de que había comprado "unas casas de morada en la dicha çibdad de Bitoria, en la calle que agora dizen la calle Real, que se solía dezir la Judería, que son entrando por la dicha calle junto con el muro, las quales dichas casas tienen un pasadizo con la dicha çerca", y que, temiendo "que alguna o algunas personas, de fecho o por fuerça, le despojaran de posesión de las dichas casas o de alguna parte dellas, o le ynquietaran e perturbaran en ella", los reyes le proveen su amparo.

30 AGS, Registro General del Sello, leg. 1493-2, núm. 230. Confirma una cédula de Isabel del 18 de noviembre de 1492 concediéndole 200.000 maravedís de lo confiscado en Jerez de la Frontera al hereje Fernando de Siles. La cédula le llama secretario y la sobrecarta camarero.

31 Vol. II, p. 122.

32 AGS, Registro General del Sello, leg. 1494-6, núm. 58, y Cámara de Castilla, Libros registro de cédulas, lib. 1 , ff. $52 \mathrm{v}-53$. 
El 11 de agosto de 1497 en Medina del Campo los Reyes Católicos firmaron las capitulaciones matrimoniales de su hija con Manuel I, y el día 15 juraron respetarlas; al pie de ambos textos lo hizo también la propia infanta, pero ahora quien refrenda es el renombrado secretario de la madre Miguel Pérez de Almazán ${ }^{33}$, de origen aragonés, hombre de confianza de Fernando, que actúa como uno de los secretarios reales desde $1492^{34}$.

El 22 de agosto de 1498, víspera de su muerte, Isabel otorgó una provisión en Zaragoza autorizada por "Gaspar de Egrizio, secretario de la rreyna y prinçesa nuestra señora" 35 . Gricio era hermano de Beatriz Galindo la Latina y había sido secretario del malogrado príncipe Juan. Isabel la Católica le había ascendido el 16 de noviembre de 1497 a una de las secretarías reales, y el 12 de octubre de 1504 dictará ante él su testamento en Medina del Campo ${ }^{36}$. En el verano de 1498 compatibilizaba, pues, la secretaría de la reina de Portugal con la de sus padres.

Aparte, el 12 de septiembre de 1498 la reina de Castilla dio cédula ordenando que se anotaran en la cuenta del tesorero Baeza diez millones de maravedís que había ido entregando, a razón de dos cuentos al año desde 1494, a "Martín de Salinas, secretario de la reyna de Portogal, mi muy cara e muy amada fija, para el gasto de los ofiçios de la Casa de la dicha reyna de Portogal". Al final dice: "los quales son demás de otros dos qüentos de maravedís que el dicho thesorero dio e pagó el año pasado de 93 a Juan de Salinas, secretario que fue de la dicha reyna de Portogal, para el gasto de los dichos sus ofiçios del dicho año" ${ }^{37}$. Es probable que desde 1494 Martín ayudara a Juan de Salinas, tal vez su padre, en la tarea de secretario de la recién fallecida Isabel, cargo que quizá venía asumiendo en solitario desde marzo de 1496, cuando se pierde el rastro escrito de Juan.

Algunos textos dan además el nombre del manufactor: "Framcisco Diaz a fez" (28 de agosto de 1491) y "Joham Rodríguez a fez" (7 y 9 de septiembre) ${ }^{38}$. Y en las cuentas de Baeza sale varias veces entre 1484 y 1496 "Diego de Alzedo, escrivano de la cámara de la prinçesa de Portugal" ${ }_{39}$.

\footnotetext{
33 ANTT, Gavetas, gaveta 17, maço 1, núm. 9, y maço 9, núm. 4.

34 Sobre él pueden consultarse: MARtín Postigo, La cancillería castellana..., pp. 230-232, y ORTEGA LóPEz, "La sociedad del valle de Ricote en los albores del siglo XVI...", pp. 326-329.

35 AGS, Registro General del Sello, leg. 1498-8, núm. 1. Era reina de Portugal desde su boda con Manuel I el 30 de septiembre de 1497, y princesa de Asturias al morir su hermano Juan el 4 de octubre de 1497 y ser jurada como tal por las Cortes de Toledo en abril (Ávila Seone, "Casos de original múltiple...”, pp. 19-20).

36 Martín Postigo, La cancillería castellana..., pp. 228-229, y Prieto Bances, Obra escrita, vol. II, pp. 500-503.

37 Solo transcribe íntegra la cédula real en el vol. II, pp. 419-420, pero el apunte contable se hace otras tres veces más (pp. 340-341, 373 y 408-409).

38 ANTT, Gavetas, gaveta 14, maço 8, núm. 8, y Corpo cronológico, parte I, maço 1, núms. 47 y 50.

39 Vol. I, pp. 67-68, 394-395, 397, 398 (dos citas), 402 y 403 (corresponde al encargo hecho el 28 de julio de 1491 de comprar la tela para el luto por el príncipe Alfonso, primer marido de la infanta), y vol. II, pp. 67 y 334.
} 


\section{Cartas de privilegio}

A falta de estudios portugueses especializados sobre este prototipo, Armando Homem sí que utiliza el término carta de privilégios hablando de los "privilégios em geral" Las dos aquí concernidas fueron despachadas en Santarem el 6 de septiembre de 1491 y van insertas en sendas confirmaciones ${ }^{41}$ registradas en los libros de Manuel I. En una, Isabel ratificaba al concejo de Torres Vedras ${ }^{42}$ un alvará de Alfonso V de 1468 eximiéndolo de hospedar a la corte itinerante, y en la otra, una provisión de 1484, su suegra Leonor prohibía al "juiz e escprivam (sic) dos órfãos" intervenir en el nombramiento de tutores ${ }^{43}$. Como es bien sabido, durante la Baja Edad Media la cancillería castellana desarrolló dos nuevos tipos diplomáticos de refrendo en pergamino: las cartas de privilegio (que corroboraban escrituras menos solemnes como albalás, provisiones o cédulas) y las cartas de privilegio y confirmación para revalidar privilegios, cartas de privilegio y otras cartas de privilegio y confirmación. Dado que los ejemplares conservados de Isabel ratifican, como acabamos de ver, un alvará y una provisión, podemos compararlos con las primeras ${ }^{44}$.

Al tratarse de copias, no es posible colegir el pergeño de los originales, aparte de que las cartas de Manuel I nunca aluden al soporte ni al sello del diploma a convalidar, lo que sí solía ocurrir en Castilla ${ }^{45}$. Esos libros registro son enteramente de pergamino, otra circunstancia exclusiva portuguesa ${ }^{46}$.

40 O desembargo régio..., pp. 84-86. Titular este epígrafe como "Cartas de privilegio" se escuda en que así las denomina el profesor Homem, pero su correspondiente en Castilla sigue otras pautas, como veremos enseguida.

41 La cancillería de los Reyes Católicos tenía dos maneras de revalidar escrituras de gracia: las cartas de privilegio (que ratificaban objetos de menor fuste, como albalás y cartas de merced) y las cartas de privilegio y confirmación (para privilegios y otras cartas de privilegio). Se acaba de indicar que nada semejante hay del lado portugués.

42 Había recibido en dote del príncipe Alfonso los señoríos de Alvaiázere, Torres Novas y Torres Vedras, así como diversas rentas pecuniarias (original: AGS, Patronato real, leg. 50, doc. 23; registrado en: ANTT, Chancelaria régia, Chancelaria de dom João II, liv. 16, f. 108; Torre y del Cerro y SuÁrez Fernández, Documentos referentes a las relaciones con Portugal..., vol. II, pp. 395-399; Alonso Ruiz, "Dos Cortes en 1490: el enlace entre Isabel de Castilla...”, p. 137, y Ávila SEOANE, "Casos de original múltiple...”, p. 18).

43 ANTT, Chancelaria régia, Chancelaria de dom Manuel I, liv. 16, ff. 130v-131 (convalidada en Lisboa el 8 de noviembre de 1499) y 131-131v (el día 20).

44 Martín Postigo, La cancillería castellana..., pp. 38-63 y 74-85; Sanz Fuentes, "Tipología documental de la Baja Edad Media...”, pp. 246-248; Marín Martínez y Ruiz Asencio, Paleografía y Diplomática, vol. II, pp. 339-341; Tamayo López-Machuca, Archivística, Diplomática y sigilografía, pp. 164-166, y LoRenZo CADARSo, El documento real..., pp. 37-44.

45 Martín Postigo, La cancillería castellana..., pp. 49-51, y Tamayo López-Machuca, Archivística, Diplomática y sigilografía, p. 165.

46 Véanse al respecto el artículo de Portugal, "A chancelaria de dom Manuel”, pp. 262-265, y la tesis de máster de FArIA, A chancelaria de dom Manuel I..., pp. 15-21. Recordar que en estas copias y en la que veremos más adelante al hablar de las provisiones, el refrendo en castellano de Salinas fue trasladado al portugués: "e eu Joam de Salinas, secretario da princesa nosa sennora, a fiz escrever e nela sobescrevy". 
La estructura consta de intitulación completa, con trato de "dona", atributo "per graça de Deus" y enumeración de títulos, primero por consorte y luego como hija de los Reyes Católicos: "primçesa dos rregnnos de Puurtugall (sic) e dos Alguarves, daquém e dalém mar em África, e do sennorio de Guinee, ifante de Castela e de Liam, d'Aragam (sic) e de Cezilia"; notificación: "a quamtos esta nosa carta virem fazemos saber"; exposición con la dirección implícita y donde consta haberse exhibido el original a sancionar ("por parte dos lavradores do noso rregemguo da nosa villa de Torres Vedras nos foy apresentado huum alvará del rrey dom Afonso que Deus aja, do quall o teor hé este que se segue"), su transcripción íntegra, la petición de ratificarlo ("pedímdonos por merçee os ditos lavradores do noso rregemguo que lhe comfirmasemos o dito alvará segundo nele hé comthenudo") y la fórmula "por thes fazer graça e merçee"; disposición convalidatoria; cláusulas prohibitiva y penal solo en la segunda carta: "e áll nom façades sob as ditas pennas comthenudas na dita carta"; fecha íntegra, bajo el incoativo "dada", y refrendo del secretario. No hay mención a sellos, aunque irían en los originales.

La cancillería castellana expedía sus cartas de privilegio sobre pergamino, generalmente en cuadernillo, y de más complejo formulario: invocación verbal, y a veces preámbulo; notificación, dirección e intitulación; cláusulas preceptivas, prohibitivas, penales y corroborativas, y múltiples validativos: suscripciones (mayordomo, notario mayor de los privilegios, canciller mayor y distintos oficiales de la contaduría mayor), refrendo del notario mayor del reino, y sello de plomo pendiente de los hilos de seda del encuadernado ${ }^{47}$.

\section{Cartas de doação o de merced}

Dentro de un genérico cartas abertas, el profesor Armando Homem distingue, en función de su contenido, las cartas de provimento de oficios, simple variante de las cartas de doação $0^{48}$, que, como vamos a ver, presentan bastantes similitudes con las de los Reyes Católicos, siendo posible distinguirlas de otras cartas régias $^{49}$, sobre todo por la fórmula "querendo fazer graça e mercê", y tratarlas como clase aparte.

La princesa Isabel se vale aquí de ellas para designar cuatro oficiales en Torres Vedras: almojarife y sesmero al escudero real Gómez Díaz el 28 de agosto de 1491; "emqueredor e contador de todollos feitos" al escudero de Pedro de Noronha ${ }^{50}$ Pedro Serrano ${ }^{51}$; "paceiro

47 Martín Postigo, La cancillería castellana..., pp. 38-63; SAnz Fuentes, "Tipología documental de la Baja Edad Media...”, pp. 246-248; Marín Martínez y Ruiz Asencio, Paleografía y Diplomática, vol. II, pp. 339-340; Tamayo LóPez-Machuca, Archivística, Diplomática y sigilografía, pp. 164-166, y LoRenzo CADARso, El documento real..., pp. 37-41.

48 O desembargo régio..., pp. 88-90 y 77-78 respectivamente.

49 Loureiro, "Reconstituição e análise da documentação...”, pp. 31-32.

50 Bastardo del arzobispo de Lisboa homónimo, fue mayordomo mayor de Juan II y señor de Cadaval (VAsconcelos, Nobreza e ordens militares..., vol. II, pp. 266-267).

51 Hubo de morir antes del 16 de enero de 1515 cuando fue sustituido por Francisco de Escobar (ANTT, Casa real, Casa da rainha dona Maria, Chancelaria da rainha e da infanta dona Isabel (Núcleo antigo, liv. 864), ff. 7v-8). 
dos nosos paços" al carpintero mayor del pueblo Juan Álvarez, y escribano del almojarifadgo al escudero Ferrán Gil, sincronizados estos tres el 7 de septiembre del mismo año ${ }^{52}$. Las cuatro son originales, de pergamino, texto apaisado que se aglutina en la parte alta y que, respetando márgenes laterales y superior, deja un amplio hueco hasta el brevete, casi al hilo del borde inferior; escritura joanina y en portugués, excepto el refrendo en cortesana de Juan de Salinas y la firma de la princesa en humanística autógrafa, que van en castellano. En la primera línea la inicial $D$ y la $I$ del nombre de la princesa abultan el módulo, y vemos estirarse alzados, caídos, signos abreviativos o rasgos marginales. La del 28 de agosto tiene mayor empaque.

\section{FIGURA 1.}

\section{Carta de doação a Gómez Díaz (28 de agosto de 1491).}

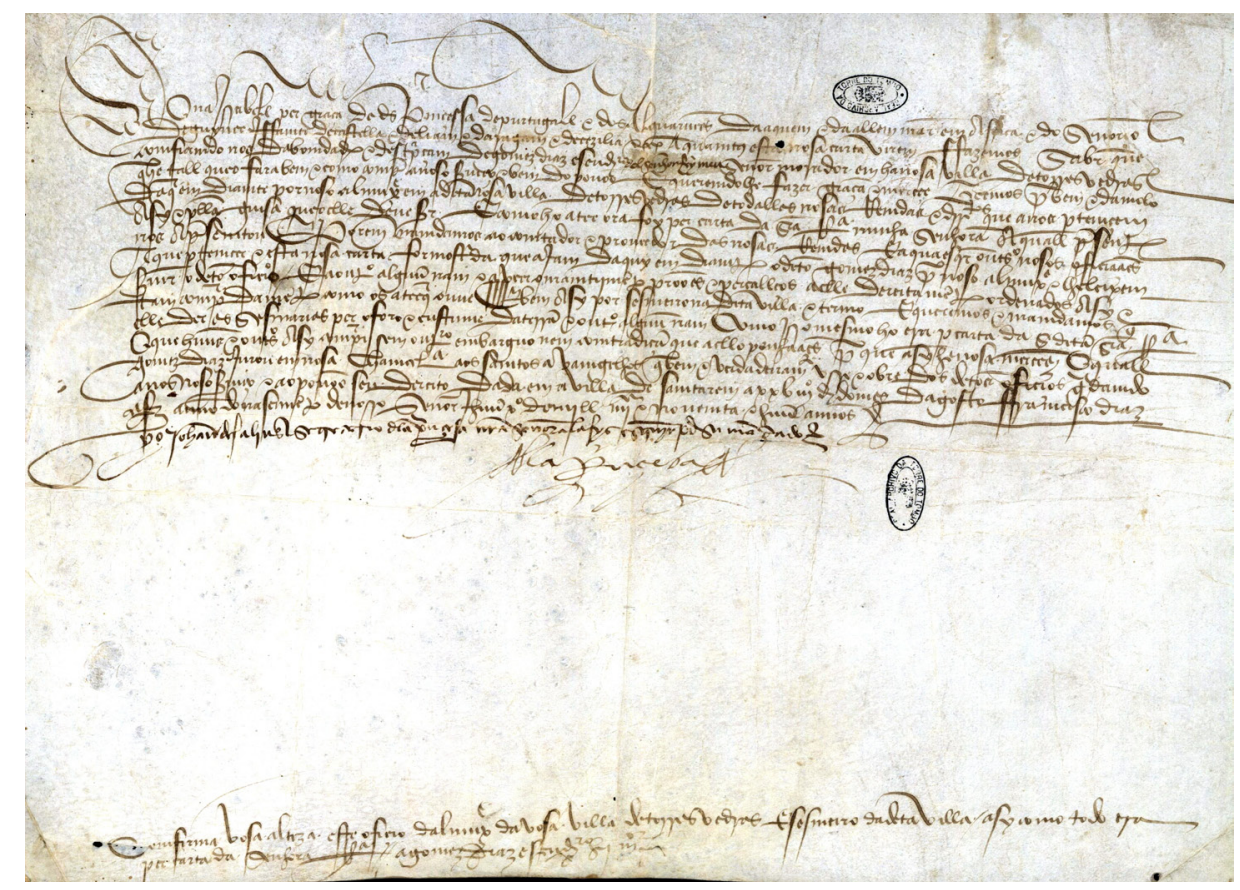

El protocolo se compone de intitulación completa ${ }^{53}$, como en las cartas de privilegio, y dirección, siempre de carácter general: "a quamtos esta nosa carta virem". El cuerpo consta de notificación ("fazemos saber"); exposición, con la dirección implícita y bajo

\footnotetext{
52 ANTT, Gavetas, gaveta 14, maço 8, núm. 8; Corpo cronológico, parte I, maço 1, núm. 49, y Gavetas, gaveta 15 , maço 6 , núm. 6 , y maço 24 , núm. 8 , respectivamente.

53 La invocativa cruz solo encabeza el nombramiento de escribano del almojarifadgo.
} 
"querendo fazer graça e mercê" ${ }_{54}$; disposición, incoada por "teemos por bem"; cláusula preceptiva a las autoridades implicadas (municipales aquí) de consentir al nuevo oficial ejercer su cargo y recibir salarios y derechos inherentes; y juramento del afectado comprometiéndose a desempeñarlo: "o quall Gomez Diaz jurou em nosa chamceleria aos samtos Avamgelhos (sic) que bem e verdadeiramemte use e obre dos dectos (sic) ofiçios, guardamdo a nós noso serviço e ao povo o seu dereito".

Data entera y abierta con "dada", pudiendo interponerse una cláusula corroborativa ("Framcisco Diaz a fez") o el refrendo del secretario, que, cuando no, subsigue a la fecha y, como ya se adelantó, siempre por mano de Juan de Salinas, en cortesana y castellano. Validan además, la firma autógrafa de la princesa y, al dorso, dos suscripciones de Juan de Salinas. Solo la intendencia para Juan Álvarez va placada por detrás con el escudo de Isabel, partido por las quinas de Portugal a diestra, y las armas de Castilla, León, Aragón y Sicilia a siniestra. Isabel la Católica había encargado al escribano de su hija Diego de Alcedo que gestionara la matriz, según consta en un apunte del 17 de junio de 1491 en las cuentas del tesorero Gonzalo de Baeza: "a los plateros milaneses para dos marcos e medio de plata, de copela e de marcar, para una guarniçión de un libro de $\mathrm{Su}$ Altesa [Isabel la Católica] e para un sello de la prinçesa, 5730 maravedís" ${ }_{55}$.

Sirven de cierre el brevete y la nota dorsal de registro.

Las tareas propias de escribano figuran en el nombramiento de Ferrán Gil:

"outrosy lhe damos liçença e logar que elhe posa poer o faça sinhall pubrico em as escrituras que ao dicto ofiçio perteençem, e feytas por elhe commo devem, façam fe commo sy por tabeliam feytas fosem. E elhe deve de as rregistar en seu livro aquelhas escrituras que de rregistar forem, para as depois dar a as partes sendolhe neçesarias, guardando nelhas os artycuos e taxaçam que he mandado aos tabeliones que guarden sob apenas nelha contendas”.

El formulario semeja al de las cartas de merced castellanas: idénticas intitulaciones; en la exposición fórmula "por fazer bien e merçed" y la doble opción al construirla; fecha íntegra bajo el participio "dada", y validan, la firma autógrafa del rey, el refrendo del secretario y un sello de placa; sin otras diferencias reseñables en Castilla que la falta de dirección general, el aumento de cláusulas, y que suscriben algunos consejeros al

\footnotetext{
54 Puntualizado así: para Gómez Díaz y Pedro Serrano, después de enumerar sus merecimientos, pone "queremdolhe fazer graça e merçee para dar paso a la disposición: comfiamdonos da bomdade e descripçam de Gomez Diaz, escudeiro del senhor rrey, meu senhor, morador em ha nosa villa de Torres Vedras, que he tall que o fará bem e como compre a noso serviço e bem do povoo, e queremdolhe fazer graça e merçee, teemos por bem e damolo...”; en cambio, para Juan Álvarez y Ferrán Gil adelanta la dirección: "querendo fazer graça e mercê a Ferram Gill, escudeiro, morador na nosa vilha de Torres Vedras, teemos por bem e damolho...". Ambas soluciones se dan también en Castilla; la primera, más habitual (MARTín Postigo, La cancillería castellana..., p. 26).

55 Torre y del Cerro y Alsina de la Torre, Cuentas de Gonzalo de Baeza..., vol. I, p. 402.
} 


\section{FiguRA 2.}

Sello de placa en la carta de doação para Juan Álvarez, y escudo de la reina María, que es el mismo de su hermana, salvo el entado de la granada, que lógicamente no veremos antes de 1492, en el Livro da nobreza e da perfeição das armas dos reis cristãos e nobres linhagens dos reinos $e$ senhorios de Portugal, manuscrito de la primera mitad del siglo XVI compuesto por António Godinho (ANTT, Casa real, Mordomia-mor, Cartório da nobreza, Nobiliários, liv. 20, f. 7v).
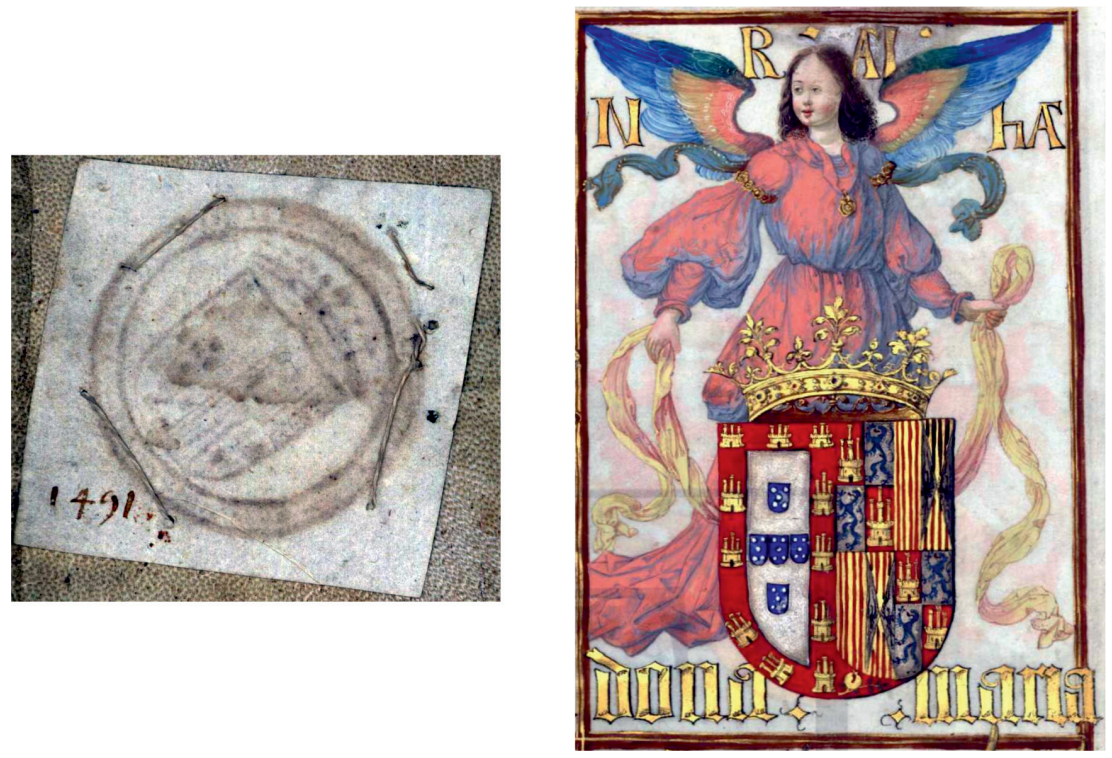

dorso. Discuerdan, eso sí, los caracteres externos: aparte del grafismo (si es que ha de considerarse un rasgo diferenciador que cada reino emplee su propia gótica documental, joanina o cortesana), el soporte: pergamino en Portugal, y papel en Castilla ${ }^{56}$.

\section{Provisiones}

Tanto Armando Homem como sus discípulos pasan por alto cualquier otra tipología dispositiva que no sea sentencia o alvará. El profesor Bernardo de Sá Nogueira sí entra concretamente en la del mandado ${ }^{57}$, pero su formulario es mucho más simple que el de los instrumentos englobados en este epígrafe, más parecidos a las cartas abertas en

56 Martín Postigo, La cancillería castellana..., pp. 19-33; Sanz Fuentes, "Tipología documental de la Baja Edad Media...”, pp. 250-251; Marín Martínez y Ruiz Asencio, Paleografía y Diplomática, vol. II, pp. 338-339; Tamayo López-Machuca, Archivística, Diplomática y sigilografía, p. 144; CARrasco LAZARENO, "Aportación al estudio de los orígenes de las cartas de merced", pp. 145-154; Lorenzo CADARSO, El documento real..., p. 37, y Puñal Fernández, "Una carta de merced de Enrique IV...”, pp. 87-107.

57 “Cartas-missivas, alvarás e mandados...”, pp. 47-48. Véase también Sara de Meneses LoureIRo, "Reconstituição e análise da documentação...”, pp. 32-33. 
general y, sobre todo, a las provisiones castellanas, con la salvedad de emitirse estas siempre en papel. Ante tales similitudes y dado que provisão puede abarcar 'certos documentos officiaes em que o Govêrno, como autoridade superior, confere cargo ou auctoriza o exercício de uma profissão, ou expede instrucções, et cetera' ${ }^{58}$, nada impide aplicar el término al grupo más numeroso de las escrituras halladas de Isabel: una copia que ordena al concejo de Torres Vedras respetar ciertos privilegios de los vasallos realengos, y ocho originales compeliéndole a aceptar otros tantos nombramientos de escribano o procurador; se otorgaron todos en Santarem los días 6, 7 y 9 de septiembre de 1491, a excepción del datado en Madrid el 20 de noviembre de 149459; luego veremos otra provisión, en este caso plenamente castellana, expedida en Zaragoza el 22 de agosto de 1498 y copiada en papel y escritura cortesana en el Registro General del Sello ${ }^{60}$.

Los originales localizados son de pergamino, con la misma disposición de texto y brevete que las cartas de merced, en portugués y de letra igualmente joanina ${ }^{61}$, menos los consabidos refrendos de Salinas y firmas de la princesa (en cortesana y humanística cursiva respectivamente, y en castellano). Se ven ahora menos grafías adornadas, a veces solo la que abre y la inicial de "Isabel". La copia primera pertenece a los libros registro de Manuel I, donde se anotó la confirmación en Lisboa el 20 de noviembre de 1499 de una provisión que Isabel había dado en Santarem el 6 de septiembre de 1491; ya queda dicho que son enteramente de pergamino.

En cuanto a las dirigidas a Torres Vedras, solo en tres campea la cruz simbólica. Nunca falta la entera intitulación, idéntica a la de las cartas de merced (trato de "dona", nombre de la princesa, locución "per graça de Deus" y lista de dominios conyugales, maternos y paternos) y lejos del simple "nós a rrainha" de mandados y albarás. Luego la dirección: "a vós", seguido del oficial designado. Cierra el protocolo la salutación ("saúde").

Incoa el cuerpo en sí la notificación ("sabede"), inmediata al expositivo, que, solo en el primer caso ${ }^{62}$ compendia el requerimiento de los vasallos realengos torrevedranos de sus privilegios, y en el resto, como confieren cargos, ocupa este apartado el nombramiento:

"sabede que, comfiandonos na bomdade e descrisam de Pero d'Almeida, criado de Gomez Soariz, morador em a dicta villa, que he tal que o fará bem

\footnotetext{
58 Figueiredo, Novo dicionário da lingua portuguesa.

59 ANTT, Chancelaria régia, Chancelaria de dom Manuel I, liv. 16, f. 130v; Gavetas, gaveta 15, maço 2, núm. 3; Corpo cronológico, parte I, maço 1, núm. 47; Gavetas, gaveta 15, maço 2, núm. 5; maço 5, núm. 21; maço 15, núm. 25; Corpo cronológico, parte I, maço 1, núm. 50; Gavetas, gaveta 15, maço 8, núm. 9, y maço 19 , núm. 49, respectivamente.

60 AGS, Registro General del Sello, leg. 1498-8, núm. 1.

61 En ocasiones tan evolucionada que se acerca a la manuelina (ANTT, Gavetas, gaveta 15, maço 2, núm. 3, y Corpo cronológico, parte I, maço 1, núm. 47), mientras que otras veces resulta palpable el influjo de la cortesana de Castilla (en particular véase Corpo cronológico, parte I, maço 1, núm. 50).

62 ANTT, Chancelaria régia, Chancelaria de dom Manuel I, liv. 16, f. 130v.
} 
FigURA 3.

Provisión al concejo de Torres Vedras (6 de septiembre de 1491).

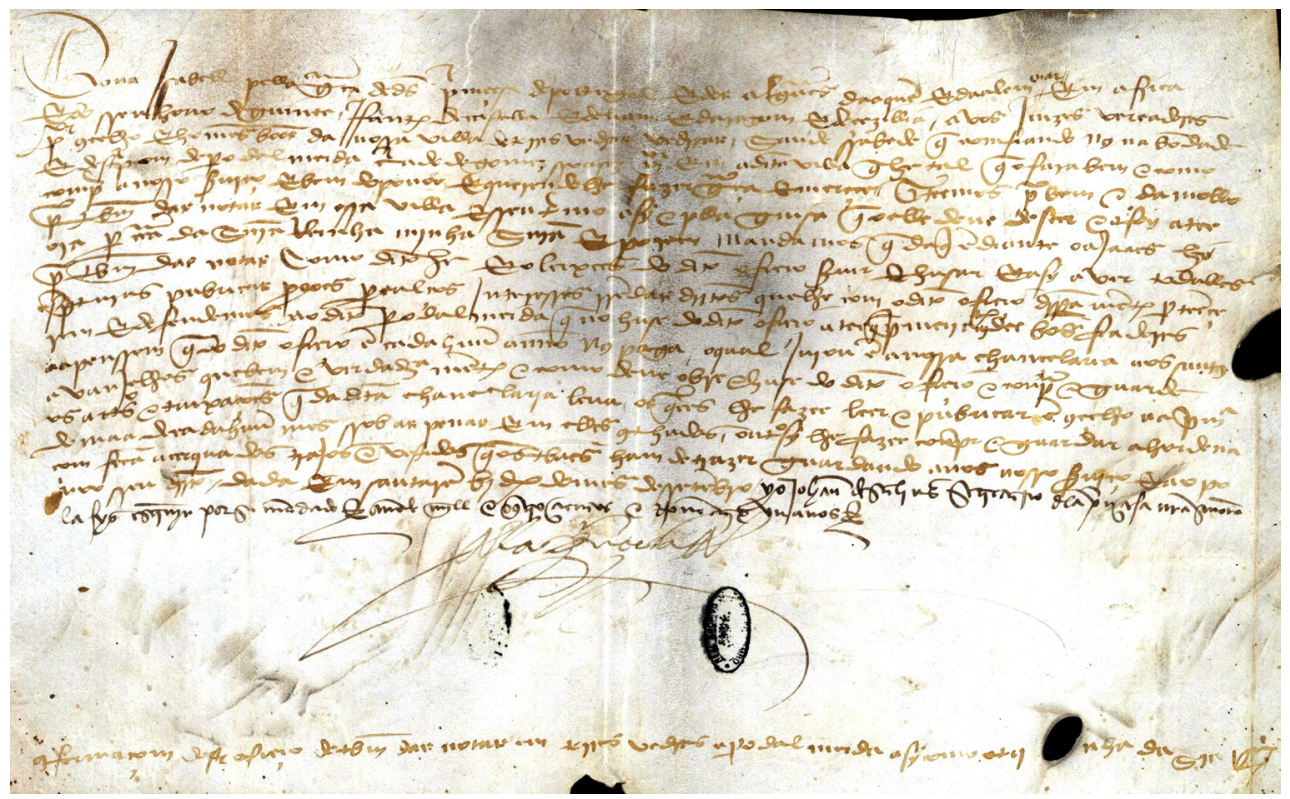

e como compre a noso serviço e bem do povoo, e querendolhe fazer graça e merçê, teemos por bem e damolle por tabeliam das notas em esa villa e seu termo, asy e pela guisa que o elle deve desta e o foy atee ora per carta da senhora rreinha, minha senhora".

De ahí que en la primera disposición la princesa, tras asentir (“teemos por bem”), ordene cumplirlo, y en las demás acatar la nominación:

"e por em vos mandamos que ajaes daquy en diemte ho dicto Afomso Periz por tabeliam do civell e crime como dito he e o leixais dele servir e husar e aver proçesos, escripturas, rrendas, foros, direitos e intereses que lhe dereytamente pertençer, sem outro enbarguo que lhe sobre ello seja posto".

Cuatro de ellas contienen fórmulas jurídico-administrativas exigiendo al recién nombrado cauciones que cubran los derechos anuales de la princesa: "e defendemoslhe que nom huse do decto hofiçio sem primeiramente dar boa fiança ao noso almoxarife, per que senpre ajamos a pensom que do dito hofiçio em cada huum anno he tindo e obrigado pagar"; y en todas jura él acatarlo. 
Las cláusulas finales escasean o ni aparecen: tres corroborativas, colocadas en medio de la data, entre el mes y el año (dos veces "Joham Rodríguez a fez", y una "dada per outra tal que apresentaram os ditos rregemgeiros"); dos prohibitivas ("e áll nom façades"), una de emplazamiento ("e se lhe alguum contra os ditos privilegios e cousas sobreditas for, em parte ou em todo, mamdamos a quallquer tabaliam dos ditos rregemgos a que ista nosa carta for mostrada que vós empraçem que em termo comvynhavell que lhe leguo pera elo, asim pareçam peramte nós por pessoa a dizer e mostrar alguuma rrazam porque nom quer cumprir e guardar") y otra penal: "se nom, sejam çertos os taees que esto asy nom comprirem que lhe será estranhado asy como aqueles que nom comprirem e guardarem noso mandado"; las cuatro últimas van entre disposición y fecha.

Esta es absoluta y bajo el participio "dada"; aparte de las tres antedichas corroborativas, en otra ocasión la interrumpe un refrendo: "dada em Santarém VI dias do mes de setembro. Yo Johán de Salinas, secretario de la prinçesa nuestra señora, la fys escrivir por su mandado. Año de mill e quatroçientos e noventa e un años".

La validación incluye ese refrendo (salvo en la procuraduría para Vasco Yáñez el 9 de septiembre de $1491^{63}$ ), la firma autógrafa de la princesa, y otras dos de Salinas a la vuelta ${ }^{64}$. Cinco de los ocho originales para el concejo de Torres Vedras llevaban el sello de placa de la princesa, pero solo uno lo conserva ${ }^{65}$; el despachado en Madrid en 1494 mantiene el arranque de la badana que hubo de atar el sello de cera ${ }^{66}$ (algo insólito para esta modalidad diplomática), cuyo diseño sería como el de las cartas de merced, pero añadiendo, tras haber finalizado la Reconquista, el entado en punta con la granada.

No suele faltar el brevete casi al borde inferior delantero y la nota dorsal de registro ${ }^{67}$. En paralelo a las cartas de merced, los formularios de las provisiones, tanto portuguesas como castellanas ${ }^{68}$, son similares (salvo la indefectible cruz cabecera de los Reyes Católicos).

Vuelve a haber en este tipo documental nombramientos de gente de pluma en Torres Vedras: los notarios municipales ("tabeliam das notas") Pedro de Almeida ${ }^{69}$ y Álvaro

\footnotetext{
${ }^{63}$ ANTT, Gavetas, gaveta 15 , maço 8 , núm. 9.

64 Ignoradas en la copia de los libros registrales, salvo una, puesta en el despacho de 1494.

65 ANTT, Gavetas, gaveta 15, maço 2, núm. 3; Corpo cronológico, parte I, maço 1, núm. 47; Gavetas, gaveta 15, maço 5, núm. 21; maço 15, núm. 25 (el que aún lo tiene), y Corpo cronológico, parte I, maço 1 , núm. 50 , respectivamente.

66 ANTT, Gavetas, gaveta 15, maço 19, núm. 49.

67 Uno y otra faltan en la copia registrada, así como el brevete en 1494 y la nota del registro en la procuraduría para Vasco Yáñez.

68 Sobre estas pueden verse: Floriano Cumbreño, Curso general de Paleografía..., pp. 526-538; Martín Postigo, La cancillería castellana..., pp. 115-128; SAnz Fuentes, "Tipología documental de la Baja Edad Media...”, pp. 251-253; Marín Martínez y Ruiz Asencio, Paleografía y Diplomática, vol. II, pp. 327-329; Tamayo López-Machuca, Archivistica, Diplomática y sigilografía, pp. 138-157, y Lorenzo Cadarso, El documento real..., pp. 46-48.

69 Renunció al cargo el 17 de octubre de 1513 y lo reemplazó Simón Vázquez (ANTT, Casa real, Casa da rainha dona Maria, Chancelaria da rainha e da infanta dona Isabel (Núcleo antigo, liv. 864), ff. 6v-7).
} 
González, y judiciales ("tabeliam do civell e crime”) Alfonso Pérez y Ruy Fernández, el escribano para hospital y leprosería ("escrivam do ospitall e gafaria”) Alfonso Pérez, y el de la almotacenía (“escripvam d'almotaçaria”) Pedro Delgado. Para los notarios hay obligación expresa de guardar las ordenanzas y tasas fijadas por la cancillería ("otrosy le fazey conprir e guardar os articuos e taxaçam que da nosa chançelleria leva, os quaes lhe fazey leer e pubricar em conçelho na primeyra domana de cada hum mes sob as penas en elhes contendos"), y de vestir la indumentaria propia del oficio: "outrosy lhe fazey guardar a hordenaçam feyta per el senhor rrey meu senhor açerca dos gajos e vestidos que aos tabaliamez de seus rregnos manda trazer" ${ }^{\prime}$.

La provisión fechada en Zaragoza en 1498 puede considerarse, por idioma y objetivo, netamente castellana, va autorizada por Gaspar de Gricio quien no solo era secretario de la reina de Portugal sino también de los Reyes Católicos, se conserva en el Registro General del Sello de Simancas, y se atiene, cómo no, al patrón de Castilla: intitulación completa de Isabel ya como reina ("doña Ysabel, por la graçia de Dios rreyna de Portogal e de los Algarbes, de aqueden (sic) e de allende de la mar en África, prinçesa de Castilla, de León e de Aragón e de Seçilia e de Granada, etçétera, señora de Guinea"); exposición, con el nombre del beneficiario y un resumen de su solicitud ("por quanto por parte de vos, el conçejo, alcaldes, alguasiles, rregidores, ofiçiales e omes buenos del logar de Castrillo ${ }^{71}$, que desís ser behetría de mar a mar destos rreynos del rrey e de la rreyna mis señores, nos es suplicado e pedido por merçed que por qu'el dicho logar fuese más honrrado e enobleçido, que vos mandásemos tomar e rreçebir en mi encomienda e tenervos de aquí adelante por mis encomendados"); disposición, encabezada por el consentimiento de Isabel ("e yo tóvelo por bien"); cláusula corroborativa ("de lo qual mandé dar e di esta mi carta firmada de mi nonbre e sellada con mi sello"); data completa, la víspera de morir; firma ("yo la rreyna y prinçesa"),

\footnotetext{
70 Ya desde las Ordenações de Alfonso V a mediados del siglo XV, el canciller real había de supervisar que cada notario "tragua sempre roupas farpadas ou de coores, de deferenças devisadas" (liv. I, tít. II). Los clérigos en cambio las tenían prohibidas, lo que unido a la obligación de contraer matrimonio de los notarios vedaba la profesión a tonsurados (COELHO, “Os tabeliães em Portugal...", pp. 178-179, y BALMORIPADESCA, "O notariado nas Ordenações afonsinas...”, p. 5).

71 Se trata de Castrillo Solarana, actualmente pedanía de Lerma en la provincia de Burgos. El pueblo era behetría de mar a mar (MARTínez DíEz, Libro becerro de las behetrías..., vol. II, p. 645), es decir, con derecho a elegir señor entre cualquier castellano. Sin embargo, tanto Santo Domingo de Silos como Solarana se disputaban su jurisdicción, y el concejo interpuso el arbitraje real. El 4 de agosto de 1497 los Reyes Católicos comisionaron al corregidor de Aranda de Duero (AGS, Registro General del Sello, leg. 1497-8, núm. 184). Un año después, como estamos viendo, los vecinos eligieron por señora a la reina de Portugal, que se murió de parto al día siguiente de haberlo aceptado; pidieron entonces que la reemplazara el recién nacido Miguel bajo tutoría de sus abuelos los Reyes Católicos, y ellos lo aceptaron en Ocaña el 19 de enero de 1499 (leg. 1499-1, núm. 4), encargando su desempeño al corregidor arandino, mediante cédula despachada diez días después (leg. 1500-8, núm. 263, ff. 1-1v). Muerto también el niño a 19 de julio de 1500, el 27 de agosto los Reyes Católicos lo asumieron personalmente a petición de los vecinos (leg. 1500-8, núm. 263, ff. 1-2).
} 
refrendo del secretario, suscripción de dos consejeros de los Reyes Católicos ("don Álvaro. Liçençiado Çapata" ${ }^{72}$ ) y sello de placa $^{73}$.

\section{Cartas de juramento}

El 11 de agosto de 1497, en Medina del Campo, los Reyes Católicos y el príncipe de Portugal Juan habían firmado las capitulaciones para el matrimonio de la, entonces y desde hacía siete años viuda, infanta Isabel con Manuel I; a continuación iba el juramento de ella comprometiéndose. Cuatro días después los reyes y el príncipe otorgaron otro juratorio de hacérsela presente al futuro marido una vez aceptados los acuerdos recién propuestos y, al dorso, lo renovó ella misma ${ }^{74}$, después de haberse resistido en viudedaz intentando meterse a monja ${ }^{75}$.

Contrariamente a lo habitual, estos compromisos no se escrituraron en forma de acta sino con carácter intitulativo. Los abre, pues, el nombre de la infanta, poniendo ya reina de Portugal aunque el matrimonio con Manuel no se celebró hasta el 30 de septiembre ("nos doña Ysabel, por la graçia de Dios rreyna de Portugal e de los Algarbes, de aquende e allende mar en África e señora de Guinea"); seguido directamente de la disposición, donde radica el juramento; una cláusula corroborativa ("por seguridad de lo qual firmamos esta de nuestras manos y la mandamos sellar con nuestro sello"), la suscripción autógrafa ("La rreyna”), el refrendo del secretario Miguel Pérez de Almazán y el sello de placa de la infanta.

Al tratarse en ambos casos de originales dúplices en los que Isabel se somete a un acuerdo anterior, presentan ciertas particularidades: solo lleva la cruz invocativa el original primigenio, y solo el duplicado lleva al pie los sellos tanto de los padres como de la hija, y aun el del procurador regio portugués Juan Manuel ${ }^{76}$ cierra el del día 11.

\footnotetext{
72 Álvaro de Portugal, hijo del segundo duque de Braganza Fernando, miembro del Consejo de Castilla, que llegó a presidir (Gan Giménez, "El Consejo real de Castilla...”, pp. 28-29, y López Beltrán y GonZÁLEZ ArÉVAlo, "Los portugueses en el reino de Granada...", p. 312). El letrado Luis Zapata fue hombre de confianza de los Reyes Católicos y perteneció a los Consejos de Estado, Guerra, Indias y Justicia (Maldonado Fernández, "El señorío alpujarreño de Çéhel en el siglo XVI", p. 239).

73 Así se deduce de la cláusula corroborativa, pues la copia del Registro General del Sello nada pone.

74 ANTT, Gavetas, gaveta 17, maço 1, núm. 9, y maço 9, núm. 4. Dicen los Reyes Católicos en la primera escritura que se facturó "doblada, de hun mismo tenor, e ambas firmadas de manos de nos, los dichos rrey e rreyna de Castilla, e del dicho illustríssimo príncipe nuestro fijo, e de mano de mí, el dicho don Juan Manuel, en nombre y como procurador del dicho rrey de Portugal, mi señor, e ambas selladas con el sello de nos, los dichos rrey e rreyna de Castilla, e con el sello de mí el dicho don Juan Manuel. Y la una queda en poder de nos, los dichos rrey e rreyna de Castilla, y la otra tomo yo, el dicho don Juan Manuel, en nombre y como procurador del dicho rrey de Portugal, mi señor"; sin embargo, falta el ejemplar castellano, que debería guardarse en Simancas.

75 Véase por ejemplo Górs, Chrónica do sereníssimo senhor rei don Manoel, p. 24.

76 El propio diploma le llama "camarero mayor y del Consejo y procurador del sereníssimo príncipe don Manuel” (f. 1). Era bastardo del difunto obispo de Guarda João Manuel de São Lourenço (1459-1476), alcalde de Santarem y hombre de confianza de Manuel I (SuÁrez Fernández, "La gran política: África o Italia...”, p. 416).
} 
Se trata de instrumentos propios de los Reyes Católicos: en castellano, sobre papel y en una humanística cursiva aún muy incipiente en la cancillería ${ }^{77}$.

En el texto primigenio el manufactor previno dos vacíos a la espera de saber dónde tendrían lugar las vistas entre los reyes de Portugal y de Castilla y consiguiente entrega de la infanta; resuelto "Çeclavín", rellenó los huecos en el mismo tipo de letra pero abultando el módulo para poder abarcarlos ${ }^{78}$; en cambio en el duplicado, de cuatro días después, el topónimo se redactó de corrido. Finalmente el encuentro no se celebró allí sino en Valencia de Alcántara por imposición de Manuel I79.

\section{FIGURA 4.}

\section{Carta de juramento de las capitulaciones para el matrimonio de la infanta Isabel y} Manuel I (11 de agosto de 1497).

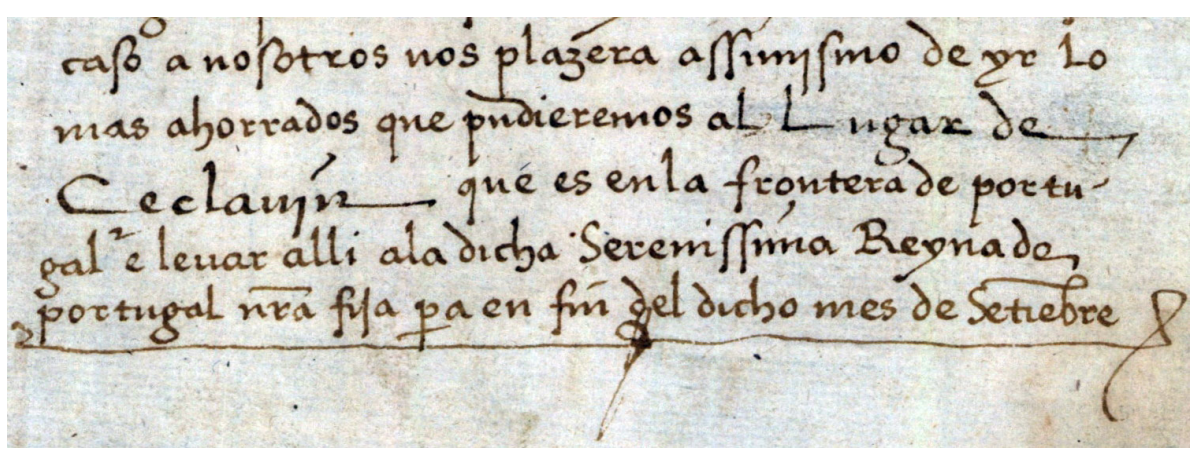

\section{Cartas misivas}

Cuatro misivas quedan de Isabel: una copia de la enviada desde Sevilla el 7 de mayo de 1490 a su suegro, el rey de Portugal Juan II, ofreciéndose a su voluntad ${ }^{80}$; la original a su padre del 13 de noviembre de 1497 desde Évora ${ }^{81}$, informándole de cómo se iba haciendo a las costumbres portuguesas, tal y como él le había augurado, y rogando a Dios venturosa preñez para su cuñada Margarita de Austria; la tercera, del día siguiente,

\footnotetext{
77 Así lo evidencia un gráfico ofrecido por RuIz AlBi, "La escritura humanística documental...”, p. 70. Sin embargo, Tomás Marín y José Manuel Ruiz Asencio indican que la humanística empezó a usarse precisamente en despachos dirigidos a otros reinos, como es el caso (Paleografía y Diplomática, vol. II, pp. 70 y 75$)$.

78 ANTT, Gavetas, gaveta 17, maço 1, núm. 9, ff. 1 y 1v.

79 SuÁrez Fernández, "La gran política: África o Italia...”, p. 416.

80 Aunque no da año ("de Sevilla a VII de mayo"), ha de ser poco posterior a la boda con el príncipe Alfonso, celebrada allí por poderes el 18 de abril de 1490 y ratificada en Évora el 27 de noviembre (ÁviLA SEOAne, "Casos de original múltiple...", p. 17).

81 Tampoco indica año pero necesariamente ha de tratarse de 1497 pues no hubo ya otro noviembre para Isabel, que falleció el 23 de agosto siguiente.
} 
al secretario Miguel Pérez de Almazán solicitándole un relato de la comisión hecha por el general de los dominicos Gioacchino Torriani ante el obispo de Salamanca Diego de Deza para reformar la orden ${ }^{82}$; y el borrador preparado en Zaragoza en julio de 1498 para agradecer a la duquesa de Cardona Aldonza Enríquez ${ }^{83}$ el interés por la salud de Isabel la Católica ${ }^{84}$. Las cuatro están en castellano y sobre papel. Las originales son autógrafas, y todo el conjunto va en humanística cursiva, la de la minuta mucho más caligráfica.

Por su condición de borrador, el de julio de 1498 presenta tachaduras, correcciones, textos interlineados..., falta por concretar el día, y obviamente no está validado: el rasgo final solo es un garabato, ajeno a la mano de Isabel, cuya firma sí que figura, como reina precisamente, al pie de las dos misivas originales de noviembre de 1497, y ahí solo pone "La rreyna", sin el "yo" de la minuta ni rúbrica alguna ${ }^{85}$. Tal vez la inopinada muerte de Isabel en el parto impidió despachar el mundum, y motivara no desechar el borrador.

FIGURA 5.

Firma de la reina en una misiva para su padre (13 de noviembre de 1497).

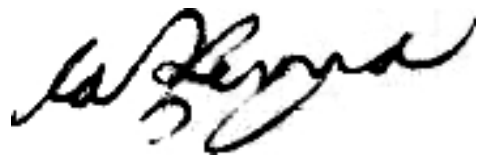

El formulario de la misiva para Juan II es muy sencillo: cláusula de sometimiento ("beso las manos"), dirección ("a Vuestra Alteza"), exposición ("por el plazer que ha mostrado"), petición, data tópica y cronológica, encabezada por la preposición "de" pero, a uso de este tipo documental, sin año; otra cláusula de sometimiento ("servidora e hija de Vuestra Alteza"), y firma de la princesa. Quizá el original llevara cruz y sello de placa.

Abre la dirigida a su padre con invocación simbólica y verbal en el centro del margen superior ("Ihesus" soportando la cruz), y un poco más abajo la dirección con tratamiento de cortesía: "muy alto y muy poderoso rrey, my señor". El bloque principal ocupa casi dos páginas y media y, tras una brevísima intitulación ("yo"), tiene carácter expositivo. Cierra, la data íntegra, análoga a la del caso anterior ("de Évora a XIII de novyenbre"), y una cláusula de sometimiento: "de Vuestra Alteza muy umyl syerva y yja que sus rreales pyes y manos besa". Fue validada, ya sabemos, con la firma autógrafa de la reina al pie del texto, y su sello de placa abrochándola, de forma que

\footnotetext{
82 BNE, RES/226/104. De nuevo omite el año, pero lo delata la reciente muerte de su hermano el príncipe Juan, acaecida en Salamanca el 4 de octubre de 1497.

83 Además de duquesa por su matrimonio con Juan Ramón Folch, doña Aldonza era hermana de Juana Enríquez y por tanto tía carnal de Fernando el Católico y tía abuela de la reina de Portugal.

${ }^{84}$ RAH, Colección Salazar y Castro, A-11, f. 39v; AGS, Patronato real, leg. 50, doc. 31, ff. 101-102v, y RAH, Colección Salazar y Castro, A-11, f. 189, respectivamente.

85 Ávila Seoane, "La escritura de las reinas de Portugal...", p. 55.
} 
el padre hubo de romperlo al abrirla, perdiendo de paso la mitad izquierda de las señas: “(cruz) [muy alt]o y muy [poderoso rrey], my señor”.

Alteran la normal conformación de las primeras misivas castellanas ${ }^{86}$ por encabezar con la cruz, omitir saludo y notificación, y abordar la fecha con "de" o "en", y no con el característico "dada”. En cualquier caso, como señala la profesora Martín Postigo, eran apoyaturas acostumbradas entonces para dirigirse a soberanos.

La remitida al secretario le nombra en vocativo, como marcaba el nuevo estilo, aunque sin destacarlo aún en el margen superior. Consta de invocación simbólica y verbal idéntica a la enviada al padre, dirección ("Almaçán”), exposición, petición, cláusula corroborativa ("de my mano"), data bajo "en" y sin año ("en Évora a XIIII de nobyenbre"), firma de la reina y, de broche a la vuelta, sello de placa y señas.

La escrita en Zaragoza para Aldonza Enríquez sigue ya a rajatabla las nuevas pautas, muy semejantes a las de la cédula: intitulación en el margen superior, separada del resto del texto ("la rreyna y prinçessa", adaptado al uso aragonés, es decir, a la izquierda y no en el centro ${ }^{87}$ ); dirección en vocativo ("egregia duquessa prima"), exposición, fórmula de cortesía ("dad mis saludos a vuestras fijas"), fecha completa, bajo "data" y con el año íntegro ("data en la ciudad de Çaragoça a (espacio en blanco) de julio, año de mil CCCCLXXXXVIII", que desentona, pues lo normal hubiera sido abrir con "de" o "fecha") y la apócrifa firma de la reina ya comentada; el despacho en limpio precisaría del refrendo del secretario.

\section{Conclusiones}

Por regla general los documentos se amoldan al uso portugués o castellano en función de adónde afecten. Así, los nombramientos de oficiales municipales o las confirmaciones de privilegios a Torres Vedras responden, a grandes rasgos, a patrones lusos, pero la provisión asumiendo el señorío de Castrillo Solarana es de factura castellana.

Lógicamente lo otorgado de soltera o viuda (casi todo negociaciones matrimoniales) responde a lo previsible en Castilla; por esa razón, la carta a su futuro suegro en 1490 va aún en castellano; lo mismo ocurre con las otras tres misivas, despachadas ya como reina, pero ahora por tener destinatario castellano: su padre, Miguel Pérez de Almazán y Aldonza Enríquez, apreciándose en esta última ese señalado y puntual influjo aragonés en la intitulación.

\footnotetext{
${ }^{86}$ La novedad de un segundo prototipo con Juan II no significó, como queda manifiesto aquí, que desapareciera el que venía expidiéndose desde el reinado de Enrique II. Sobre misivas en general pueden verse: Floriano Cumbreño, Curso general de Paleografía..., pp. 539-540; Martín Postigo, La cancillería castellana..., pp. 132-135; SAnz Fuentes, "Tipología documental de la Baja Edad Media...", pp. 253-254; Marín Martínez y Ruiz Asencio, Paleografía y Diplomática, vol. II, pp. 330-332; TAmayo LóPez-Machuca, Archivística, Diplomática y sigilografía, pp. 160-161, y Lorenzo CADARso, El documento real..., pp. 48-49.

87 Galende Díaz, "Diplomática regia: la cédula real...”, p. 81.
} 
Isabel dispuso de secretarios y escribanos de Castilla, no siempre duchos en el hacer portugués. Los despachos para Torres Vedras responden con bastante exactitud a los formularios lusos, extendidos en su lengua con grafía joanina o manuelina; solo disuena el refrendo del secretario Juan de Salinas, en castellano y buena letra cortesana.

Cuando escribe a su padre, lo hace de su puño y letra, igual que la misiva al secretario Almazán, que además, lo manifiesta: "de my mano" ${ }_{88}$. Y firmó siempre en su lengua materna: "La prinçesa", "La rreyna" o "Yo la rreyna y prinçesa".

$\mathrm{Al}$ contrastar las formas gráficas portuguesas y castellanas, se ve que ambas cancillerías siguen manteniendo, salvo puntuales desviaciones, las góticas documentales (cortesanas, joaninas y manuelinas), con más o menos influjo de la recién eclosionada humanística, que aún no logra prender; la infanta en cambio sí emplea ya el surgiente modelo gráfico ${ }^{89}$.

Por lo tocante a formularios, los portugueses suelen ser más sencillos, con menos cláusulas; pero de más costoso soporte, pues plasma en pergamino modalidades que en Castilla son de papel (provisões ${ }^{90}$ y cartas de doação).

\section{Bibliografía}

Almeida, Ana Paula Pereira Godinho, A chancelaria régia e os seus oficiais em 1462, Universidade do Porto (tesis de máster), Porto, 1996.

Alonso Ruiz, Begoña, "Dos cortes en 1490: el enlace entre Isabel de Castilla y don Alfonso de Portugal", Artis, 3 (2004), pp. 123-139.

- "Doña Isabel de Castilla, entre la magnificencia castellana y la portuguesa. Ceremonias del enlace con el príncipe don Alfonso", La reina Isabel y las reinas de España: realidad, modelos e imagen historiográfica, María Victoria López-Cordón Cortezo y Gloria Ángeles Franco Rubio (coords.), Fundación Española de Historia Moderna, Madrid, 2005, pp. 105-122.

— "La muerte de la reina de Portugal en Zaragoza en 1498: duelo, patronazgo artístico y ajuar doméstico", Actas do IV Congresso de História da Arte portuguesa em homenagem a José Augusto França, Begoña Farré Torras (coord.), Associação Portuguesa de Historiadores da Arte, Lisboa, 2012, pp. 242-246.

\footnotetext{
88 Las cartas a familiares directos no precisaban especificar el carácter autógrafo, pues el destinatario identificaba bien la mano (Ávila SeOAne, "La escritura de las reinas de Portugal...", p. 72).

89 Ávila Seoane, "La escritura de las reinas de Portugal...", pp. $42-55$.

90 Como hemos visto, el estudio aquí realizado solo incluye ocho provisiones portuguesas originales, y todas se emplean para ordenar al concejo de Torres Vedras que respete nombramientos de oficiales municipales hechos por Isabel. Teniendo en cuenta que no hay carta de merced paralela en ninguno de los casos, cabe pensar que esos documentos se entregaran a los beneficiarios para que pudieran exhibirlos como título de propiedad. Y quizá por ello se expidieran en pergamino, material que lógicamente no sería reglamentario para todas las provisiones.
} 
— "Emmanuelis iter in Castellam: el viaje de los reyes de Portugal por Castilla en 1498”, Las Artes y la arquitectura del poder, Víctor Manuel Mínguez Cornelles (ed.), Universidad Jaime I, Castellón de la Plana, 2013, pp. 2537-2554.

Ávila Seonne, Nicolás, "Casos de original múltiple sobre la primogénita de los Reyes Católicos en archivos municipales castellanos", Madrid: su pasado documental, Juan Carlos Galende Díaz y Susana Cabezas Fontanilla (dirs.), Universidad Complutense de Madrid, Madrid, 2015, pp. 7-115.

— "Documentos de las hijas de los Reyes Católicos: Isabel", De Medio Aevo, 8 (2015), pp. 163-194.

— "La escritura de las reinas de Portugal Isabel y María, hijas de los Reyes Católicos", Historia. Instituciones. Documentos, 44 (2017), pp. 39-76.

BAlmori-PAdesca, Ana Luísa: "O notariado nas Ordenações afonsinas, contributo para o seu estudo", pp. 1-10 (artículo disponible en la página web Ordem dos notários. Portugal, http://www.notarios.pt/NR/rdonlyres/11BE742A-FDDF-484D8949-D03DB6362C50/52/EstudoDraAnaLu\%C3\%ADsaBalmori.pdf [25 de febrero de 2019]).

Berwanger, Ana Regina y Leal, João Eurípedes Franklin, Noções de Paleografia e Diplomática, Editora da Universidade Federal de Santa Maria, Santa María, 2008 (3 ${ }^{\text {a }}$ ed. revisada y ampliada).

Borlido, Armando Paulo Carvalho, A chancelaria régia e os seus oficiais em 1463, Universidade do Porto (tesis de máster), Porto, 1996.

Burnam, John Miller, Palaeographia Iberica. Fac-similés de manuscrits espagnols et portugais (IXe-XVe siècles), avec notices et transcriptions, Éditions Honoré Champion, París, 1912-1925.

CAPAs, Hugo Alexandre Ribeiro, A chancelaria régia e os seus oficiais no ano de 1469 , Universidade do Porto (tesis de máster), Porto, 2001.

Carrasco Lazareno, María Teresa: “Aportación al estudio de los orígenes de las cartas de merced", Signo. Revista de Historia de la Cultura Escrita, 5 (1998), pp. 145-154.

Carvalho, António Eduardo Teixeira de, A chancelaria régia e os seus oficiais em 1468, Universidade do Porto (tesis de máster), Porto, 2001.

Coelho, Maria Helena da Cruz, "Os tabeliães em Portugal, perfil profissional e sócioeconómico (séculos XIV-XV)”, Historia. Instituciones. Documentos, 23 (1996), pp. 173-212.

Coelho, Maria Teresa Pereira, Existiu uma escrita manuelina?: estudo paleográfico da produção gráfica de escrivães da Corte régia portuguesa (1490-1530), Universidade de Lisboa (tesis de máster), Lisboa, 2006.

Cordeiro de Sousa, José María, "Notas acerca de la boda de Isabel de Castilla con el príncipe don Alfonso de Portugal", Revista de Archivos, Bibliotecas y Museos, 60 (1954), pp. 33-51. 
Costa, Avelino de Jesus da, "La chancellerie royale portugaise jusq'au milieu du XIII siècle", Estudos de Cronologia, Diplomatica, Paleografia e histórico-linguísticos, Sociedade Portuguesa de Estudos Medievais, Porto, 1992, pp. 137-166.

Cruz, António, Paleografia portuguesa: ensaio de manual, Universidade Portucalense, Porto, 1987.

Cunha, Maria Cristina de Almeida e, "Alguns tabeliães do Algarve durante a Idade Média”, Revista de História, 7 (1987), pp. 151-158.

FARIA, Diogo, A chancelaria de dom Manuel I. Contribução para o estudo da burocracia régia e dos seus oficiais, Universidade do Porto (tesis de máster), Porto, 2013.

- "A burocracia régia e os seus oficiais no tempo de dom Manuel I", Revista Portuguesa de História, 45 (2014), pp. 587-607.

Fernández Luzón, Antonio, "Isabel de Castilla y Aragón”, Diccionario biográfico español, Real Academia de la Historia, Madrid, 2011, vol. XXVII, pp. 400-402.

Ferreira, Ana Cristina Pereira da Silva, Análise paleográfica de uma escrita de chancelaria régia: a letra joanina, 1370-1420, Universidade de Lisboa (tesis de máster), Lisboa, 2011.

Figueiredo, Cándido de, Novo dicionário da lingua portuguesa, Livraria Editôra Tavares Cardoso \& Irmão, Lisboa, 1899.

Floriano Cumbreño, Antonio Cristino, Curso general de Paleografía, y Paleografía y Diplomática españolas, Universidad de Oviedo, Oviedo, 1946.

FreitAs, Judite Antonieta Gonçalves de, «Teemos por bem e mandamos»: a chancelaria régia e os seus oficiais em meados de Quatrocentos (1439-1460), Universidade do Porto (tesis doctoral), Porto, 1999.

- "Chancelarias régias quatrocentistas portuguesas: produção manuscrita e aproximação político-diplomática", Revista da Faculdade de Ciências Humanas e Sociais, 6 (2009), pp. 136-150.

- "The royal chancellery at the end of the portuguese Middle Ages: diplomacy and political society (1970-2005)", e-Journal of Portuguese History, 7-2 (2009), pp. 1-23. Galende DíAz, Juan Carlos, "Diplomática regia: la cédula real en la documentación trastámara y habsbúrgica”, Boletín de la Sociedad Castellonense de Cultura, 78 (2002), pp. 79-103.

Gan Giménez, Pedro, "El Consejo real de Castilla. Tablas cronológicas (1499-1558)", Chronica Nova, 4-5 (1969), pp. 5-179.

Góis, Damião de, Chrónica do sereníssimo senhor rei don Manoel, Miguel Manescal da Costa, Lisboa, 1749 (la príncipe es de 1566-1567).

Gomes, Saul António, “O notariado medieval português. Algumas notas de investigação”, Humanitas, 52 (2000), pp. 241-286.

Guimarães SÁ, Isabel dos, Rainhas consortes de dom Manuel I, Círculo de Leitores, Lisboa, 2012. 
Homem, Armando Luís de Carvalho, O desembargo régio (1320-1443), Universidade do Porto (tesis doctoral), Porto, 1985.

López Beltrán, María Teresa y González Arévalo, Raúl, "Los portugueses en el reino de Granada en época de los Reyes Católicos (Málaga, 1487-1518)", Baetica. Estudios de Arte, Geografia e Historia, 24 (2002), pp. 309-338.

Lorenzo Cadarso, Pedro Luis, El documento real en la época de los Austrias (15161700), Universidad de Extremadura, Cáceres, 2001.

Loureiro, Sara de Meneses, Afonso Mexia, escrivão da Câmara e da Fazenda de dom Manuel I e de dom João III: reconstituição e análise da sua actividade como redactor e escrivão de diplomas régios, Universidade de Lisboa (tesis de máster), Lisboa, 2006.

- "Reconstituição e análise da documentação produzida por Afonso Mexia, escrivão da Câmara e da Fazenda de dom Manuel I e de dom João III", Cadernos do Arquivo Municipal, 9 (2007), pp. 10-47.

Maldonado Fernández, Manuel, "El señorío alpujarreño de Çéhel en el siglo XVI", Chronica Nova, 30 (2003-2004), pp. 237-264.

Marín Martínez, Tomás y Ruiz Asencio, José Manuel, Paleografía y Diplomática, UNED, Madrid, 1991 ( $5^{\mathrm{a}}$ ed.).

Marques, António Henrique Rodrigo de Oliveira, Dias, João José Alves y Rodrigues Teresa Ferreira, Álbum de Paleografia, Editorial Estampa, Lisboa, 1987.

Marques, João Martins da Silva, Estudos de Paleografia portuguesa, Lisboa, 1938.

Marques, José, "Práticas paleográficas em Portugal no século XV", Revista da Faculdade de Letras. Ciências e Técnicas do Património, $1^{\mathrm{a}}$ serie, 1 (2002), pp. 73-96.

Martín Postigo, María de la Soterraña, La cancillería castellana de los Reyes Católicos, Universidad de Valladolid, Valladolid, 1959.

Martínez Alcorlo, Ruth, "La literatura en torno a las hijas de los Reyes Católicos: inicios de una tesis doctoral", Dicenda. Cuadernos de Filología Hispánica, 30 (2012), pp. 253-266.

- Antonio de Nebrija: Epithalamivm en honor de las bodas de la infanta Isabel de Castilla y el príncipe Alfonso de Portugal, Ediciones Clásicas, Madrid, 2013.

- "El Epithalamium de Antonio de Nebrija y la Oratio de Cataldo Parisio Sículo: dos ejemplos de literatura humanística para la infanta Isabel de Castilla", Estudios de literatura medieval en la Península Ibérica, Carlos Alvar Ezquerra (coord.), Centro Internacional de Investigación de la Lengua Española, San Millán de la Cogolla, 2015, pp. 955-972.

- La Literatura en torno a la primogénita de los Reyes Católicos: la infanta Isabel de Castilla y Aragón, princesa y reina de Portugal (1470-1498), Universidad Complutense de Madrid (tesis doctoral), Madrid, 2016.

- "«Estampas para un libro»: la infanta Isabel de Castilla, reina de Portugal, en la literatura de los siglos XX y XXI", Reinas e infantas en los reinos medievales ibéricos. 
Contribuciones para su estudio, Silvia Cernadas Martínez y Miguel García Fernández (coords.), Universidad de Santiago de Compostela, Santiago de Compostela, 2018, pp. 509-530.

Martínez Díez, Gonzalo, Libro becerro de las behetrías. Estudio y texto crítico, Centro de Estudios e Investigación San Isidoro, León, 1981.

MatA, Luís António, “Alguns profissionais da escrita na Santarém de Quatrocentos. A fama e o proveito", Revista Portuguesa de História, 32 (1997-1998), pp. 149-182.

Monteiro, Helena Maria Matos, A chancelaria régia e os seus oficiais (1464-1465), Universidade do Porto (tesis de máster), Porto, 1997.

Montes Romero-CAmacho, Isabel, "Un episodio más de las relaciones político-familiares hispano-portuguesas durante la Edad Media: el matrimonio de la infanta Isabel de Castilla, primogénita de los Reyes Católicos, y el príncipe don Alfonso, heredero de Portugal (1490)", Os reinos ibéricos na Idade Média: livro de homenagem ao professor doutor Humberto Carlos Baquero Moreno, Luis Adáo da Fonseca, Luis Carlos Amaral y Maria Fernanda Ferreira Santos (coords.), Livraria Civilizaçào Editora, Porto, 2003, vol. II, pp. 539-550.

Nogales Rincón, David, "Las lágrimas de la infanta de Castilla y princesa de Portugal, doña Isabel, y las del elefante del rey portugués Manuel I, Annón, a fines de la Edad Media", Des cris et des larmes du Moyen Âge à nos jours, Flora Ramires Velis (coord.), Université Sorbonne-Nouvelle Paris 3, París, 2011, pp. 108-128.

- "La cultura del pacto en las relaciones diplomáticas luso-castellanas durante el período Trastámara (1369-1504)”, En la España Medieval, 35 (2012), pp. 121-144.

— "Los proyectos matrimoniales hispano-portugueses durante el reinado de los Reyes Católicos y los sueños de unión ibérica", De Medio Aevo, 2-2 (2013), pp. 43-68.

NunEs, Eduardo Alexandre Borges, Álbum de Paleografia portuguesa, Centro de Estudos Históricos, Lisboa, 1969, vol. I.

Ortega López, Dimas, "La sociedad del valle de Ricote en los albores del siglo XVI: la encomienda de Miguel Pérez de Almazán", III Congreso turístico cultural del valle de Ricote "Despierta tus sentidos". Ojós, 25 y 26 de noviembre de 2005. Compilación de ponencias, María Cruz Gómez Molina (coord.), Mancomunidad Valle de Ricote, Archena, 2005, pp. 307-336.

Paulo, Jorge Ferreira, A escrita humanística na documentação régia portuguesa de Quinhentos, Universidade de Lisboa (tesis de máster), Lisboa, 2006.

Pereira, Isaías da Rosa, "O tabelionado em Portugal”, Notariado público y documento privado: de los orígenes al siglo XIV, Generalitat Valenciana, Valencia, 1989, vol. I, pp. 615-700.

Portugal, Fernando, “A chancelaria de dom Manuel”, Ethnos, 6 (1969), pp. 261-270.

Prieto Bances, Ramón, Obra escrita, Universidad de Oviedo, Oviedo, 1976. 
Puñal Fernández, Tomás, "Una carta de merced de Enrique IV y su confirmación por Juana I a la iglesia de Santa María de la Almudena de Madrid", Boletín de la Real Academia de la Historia, 205-1 (2008), pp. 87-107.

Román Blanco, Ricardo, Estudos paleográficos, Laserprint, São Paulo, 1987.

Ruiz Albi, Irene, "La escritura humanística documental durante el siglo XVI. El panorama castellano a través de la documentación de Cámara de Castilla (Archivo de Simancas)", Paleografía III: la escritura gótica (desde la imprenta hasta nuestros días) y la escritura humanística, Blas Casado Quintanilla y José Miguel López Villalba, UNED, Madrid, 2011, pp. 47-71.

Rumeu de Armas, Antonio, Itinerario de los Reyes Católicos, CSIC, Madrid, 1974.

Sá Nogueira, Bernardo Maria Godinho de, "Cartas-missivas, alvarás e mandados enviados pelos reis dom João II e dom Manuel ao concelho de Montemor-o-Novo (estudo diplomatístico)", Almansor. Revista de Cultura, 8 (1990), pp. 43-129.

- Tabelionado e instrumento público em Portugal: génese e implantação, Universidade de Lisboa (tesis de doctorado), Lisboa, $1996^{91}$.

SAntos, Maria José Azevedo, "Alguns aspectos do tabelionado em Coimbra (séculos XIV-XV)", Arquivo Coimbrão, 33-34 (1990-1992), pp. 125-150.

- Ler e compreender a escrita na Idade Média, Edições Colibri, Lisboa, 2000.

SAnz Fuentes, María Josefa, “Tipología documental de la Baja Edad Media castellana. Documentación real", Archivística. Estudios básicos, Diputación Provincial de Sevilla, Sevilla, 1981, pp. 237-256.

SAnz Hermida, Jacobo, “A vos Diana primera leona: literatura para la princesa y reina de Portugal, la infanta Isabel de Castilla", Península. Revista de Estudios Ibéricos, 1 (2004), pp. 379-394.

SARAIVA, Anísio Miguel de Sousa, "Tabeliães e notários de Lamego na primeira metade do século XIV”, Humanitas, 50 (1998), pp. 587-624.

SuÁRez Fernández, Luis, "La gran política: África o Italia (1492-1504)”, Historia de España, Ramón Menéndez Pidal (dir.), Espasa Calpe, Madrid, 1969, vol. XVII-2, pp. 309-642.

SuÁrez Fernández, Luis y EzQuerra Abadía, Ramón, "Isabel, infanta de Castilla y Aragón”, Diccionario de Historia de España, Germán Bleiberg (dir.), Alianza Editorial, Barcelona, 1986 (1952), vol. II. pp. 506-507.

Tamayo López-Machuca, Alberto, Archivística, Diplomática y sigilografía, Cátedra, Madrid, 1996.

Tereno, Isaura Pereira Fernandes, Provisões régias recebidas pela cidade de Lisboa: 1565-1585: estudo diplomatístico, Universidade de Lisboa (tesis de máster), Lisboa, 2006.

91 Editada en 2008 en Lisboa por la Imprensa Nacional Casa da Moeda. 
— "Estudo das provisões régias recebidas pela cidade de Lisboa (1565-1585). O rei e a cidade, homens e ofícios", Cadernos do Arquivo Municipal, $2^{\mathrm{a}}$ serie, 2 (2014), pp. 55-101. Torre y del Cerro, Antonio de la y Alsina de la Torre, Engracia, Cuentas de Gonzalo de Baeza, tesorero de Isabel la Católica, CSIC, Madrid, 1955-1956.

Torre y del Cerro, Antonio de la y SuÁrez Fernández, Luis, Documentos referentes a las relaciones con Portugal durante el reinado de los Reyes Católicos, CSIC, Valladolid, 1958-1963.

Vasconcelos, António Maria Falção Pestana de, Nobreza e ordens militares. Relações sociais e de poder (séculos XIV a XVI), Universidade do Porto (tesis doctoral), Porto, 2008. 
